\title{
Reframing the university as an emergent organization: Implications for Strategic Management and Leadership in Higher Education
}

\author{
Tom Doyle \\ Independent Researcher, \\ Dublin, Ireland \\ Tel. +353892506658 \\ Email: tom.doyle@cuyahogaconsulting.com \\ Malcolm Brady* \\ DCU Business School, \\ Dublin City University \\ Dublin 9, Ireland \\ Tel. +35317005188 \\ Email: malcolm.brady@dcu.ie \\ *corresponding author
}

Published as:

Doyle, T. and Brady, M. 2018. Reframing the university as an emergent organization: Implications for strategic management and leadership in Higher Education, Journal of Higher Education Policy and Management 40(4):305-320. 


\title{
Reframing the university as an emergent organization: Implications for Strategic Management and Leadership in Higher Education
}

\begin{abstract}
For the most part, the organisational forms that are currently being adopted by higher education institutions are grounded in the traditional corporate models of organisation that take a rational approach to organisational design and change management. Underlying this account is an assumption of organisational autonomy and the capacity of designated leaders to direct change processes to better align their institutions with societal demands or goals. However, a case is now being made for the consideration of alternative organisational theories or models that offer a different perception on the sources and patterns of organisational change in higher education. These theories perceive organisations more as emergent entities in which change is continuous, often unpredictable and arising mainly from local interactions. The paper surveys the implications that acceptance of the alternative paradigm might have for strategising and change leadership in higher education institutions. It suggests that the accommodation of these alterative paradigms of institutional development in higher education may itself be an emergent process and considers how future research and policy formulation relating to strategic management and leadership might facilitate positive outcomes in that process.
\end{abstract}

\section{Introduction}

Recent decades have seen higher education being steered towards a more rational and accountable form of governance, a process described by Krücken \& Meier (2006) as turning the university into an organisational actor. Institutional theorists explain the transition of public and professional bodies like higher education institutions (HEIs) towards this organisational model in the context of a general rational transformation in world society (Ramirez, 2012). In this context, HEIs are increasingly rationalised as sovereign organisational actors that are expected to commit themselves to the goals of greater accessibility and social and economic relevance and are actively encouraged in this direction by national and transnational policy bodies. As an organisational actor, the institution possesses a degree of sovereignty and rationality that was absent in the state centred or academic led institutions of the past. Brunsson \& Sahlin-Anderson (2000) describe the essential characteristics of this modern organisational form as having a distinct identity and a rational approach to directing organisational change and resource management so as to better align the institution with societal demands. The approach assumes a clear statement of institutional goals and strategy and a structured leadership with sufficient autonomy and capacity to deliver such change.

The adoption of this rational approach to the organisation of higher education has not been without difficulty or dissent. A case is now emerging for the consideration of alternative theorisations of higher education based on a different paradigm of what constitutes an organisation and how organisational change occurs. Scholars have pointed to the limitations of applying an organisational form that may not correspond to the realities of life in higher education: its traditions or national context, its internal complexity and unique form of governance, the complexity of its environment and the open ended nature of its core 
activities of teaching and research (Musselin,2006; Whitley, 2008). Others have questioned whether there is substantial evidence linking the adoption of this organisational form and institutional performance (Enders et al 2013; Stacey, 2011). A critical literature suggests the main purpose of this rational approach is as a means of facilitating managerialism (Deem \& Brehony, 2005), academic capitalism (Slaughter \& Rhoades, 2004) or the marketisation of higher education with consequent negative effects on academic well-being and the quality of teaching and research (Franco-Santos et al, 2017; Molesworth et al, 2010).

These limitations have prompted other writers to call for a broader range of organisational perspectives to be deployed in devising governance arrangements in higher education that more accurately reflect the nature of organisational life in higher education and how it responds to complexity of changes that are occurring at both local and global level. To do that, they suggest that current rational systems theories that emphasise alignment of higher education with the needs of the external environment must be combined with others that focus more on the core work of HEIs, with the human dynamics involved in that work and how such work brings about institutional change (Bastedo, 2012; Bolman \& Gallos, 2011; Frølich et al, 2013; Kezar, 2013a; Kezar et al, 2006; Manning, 2013; Marginson, 2006; Scott, 2015). As Marginson puts it, any alternative theorisation should be capable of addressing the many changes that are happening in the field of higher education and society but equally importantly, 'its own varying, inner capacity for self-alteration' (2006, p.45 )

Following this reasoning, we point to an alternative emergent paradigm of organisational dynamics to the current rational model and outline how it reframes discussions on strategy and change leadership in higher education. We suggest that the task of accommodating this paradigm may itself be an emergent change process. Based on our understanding of such processes, and insights gained from our own administrative and academic experience in higher education, we outline an approach to research and policy formulation that might increase the chances of more favourable outcomes in terms of institutional form and performance. In doing so, we hope to strengthen the argument for the wider use organisational theory to provide a clearer and more consistent framework in which to discuss issues of governance, leadership and the management of change in higher education (Kezar et al, 2006; Manning, 2013; Scott, 2015)

\section{Alternative Paradigms of Organisation of Higher Education}

The core perception of an organisation is of a group of people with a shared purpose or set of goals, a common technology or way of doing things, and a social structure that enables them to relate to each other and to outsiders in pursuit of their organisational goals (Scott \& Davis, 2007). However, depending on the researcher discipline and reason for analysis, there are multiple theories about how people interact in pursuit of those goals or how collective action comes about in a way that is directed towards that common purpose. The focus of this paper is on how change is initiated and enacted in HEIs. Rather than consider a spectrum of theories, we draw on the opposing typologies that contrast current rational theory with an emergent paradigm of organisational change (Stacey, 2011; Van de Ven \& Poole, 1995, 2005; Weick \& Quinn, 1999). The former is based on a rational positivist philosophy describing the organisation as an imposed and controllable system, the latter on an alternative process philosophy that depict organisations as emergent entities in a continuous state of change arising from day to day interactions between organisational members. This emergent paradigm is now gaining greater currency within the practice of organisational development resulting in a shift from a rational diagnostic, and top down, approach to the initiation and enactment of strategic change to a dialogic one that focuses more on how organisational 
discourse and conversation bring about change at all levels ( Bushe \& Marshak, 2015; Grant \& Marshak, 2011; Hardy et al, 2005; Scharmer, 2009; Stacey, 2011; Tsoukas \& Chia, 2002). 
Table 1 Alternative Perceptions of Organisations and Organisational Change

\begin{tabular}{|c|c|c|}
\hline Dimension & Rational Paradigm & Alternative Emergent Paradigm \\
\hline $\begin{array}{c}\text { Nature } \\
\text { of Organisations }\end{array}$ & $\begin{array}{l}\text { A 'thing, a noun', a social actor, a structured entity, organisation is imposed (Van } \\
\text { de Ven \& Poole, 2005). }\end{array}$ & $\begin{array}{l}\text { A verb, a process of emergence or flux, order from } \\
\text { disorder, organisation emerges spontaneously from human interaction (Van de Ven \& } \\
\text { Poole, 2005). Is perceived as in a state of constant becoming (Tsoukas \& Chia 2002). }\end{array}$ \\
\hline Perspective & $\begin{array}{l}\text { External, macro, objective, based on abstractions of organisational experience. } \\
\text { Involves simplification of complex phenomena. Linear causality applies with } \\
\text { predictable outcomes. At any time, there is a single organisational reality which } \\
\text { can be discovered using rational analytic processes (Stacey, 2011). }\end{array}$ & $\begin{array}{l}\text { Internal, micro, subjective, based on immersion in local interaction. Complex thinking that } \\
\text { embraces ambivalence and paradox. Multiple causality with unintended consequences. At } \\
\text { any time, there are several organisational realities at play. Realities are socially constructed } \\
\text { and may be determined by local power configurations (Stacey, 2011). }\end{array}$ \\
\hline $\begin{array}{l}\text { Analysis of } \\
\text { Organisational } \\
\text { Change }\end{array}$ & $\begin{array}{l}\text { Focus is on a process of transition, on tasks and activities, } \\
\text { on how organisations 'should be governed' (Stacey, 2015, p151). } \\
\text { Change is perceived as episodic, an observed difference over time, a disruption of } \\
\text { equilibrium which is reverted to at the end of the change process (Van de Ven \& } \\
\text { Poole, 2005, Weick \& Quinn 1999). } \\
\text { Motor of change is teleological, based on assumption that purpose or goal setting } \\
\text { is what initiates and directs progress in organisations (Van de Ven \& Poole, 1995, } \\
\text { p. 516). Change is driven from top down to align the organisation with } \\
\text { external environment. }\end{array}$ & $\begin{array}{l}\text { Focus is on what is actually happening- on the 'ordinary everyday life } \\
\text { in organisations' (Stacey, } 2015 \text { p.155) or on the human interactions which bring change } \\
\text { about - specifically on prevailing narratives and conversations through which people make } \\
\text { meaning about organisational life and direction (Grant \& Marshak, 2011a). } \\
\text { Change is envisaged as 'endless modifications of work processes and social practice' that } \\
\text { can cumulate and amplify to produce new organisational or field patterns (Weick and } \\
\text { Quinn, 1999, p.366). } \\
\text { Motor of change is dialectic driven by organisational diversity and conflicting ideas that } \\
\text { either express continuity or transform individual and collective identity (Van de Ven \& } \\
\text { Poole, p. 517, 1995, Stacey, 2011). }\end{array}$ \\
\hline \multirow[t]{2}{*}{$\begin{array}{l}\text { Strategic } \\
\text { Management } \\
\text { and Leadership }\end{array}$} & $\begin{array}{l}\text { Objective is to bring about change according to a prescribed model or some other } \\
\text { future desired state. Approach is based on Lewinian theory of change as a process } \\
\text { of 'unfreeze, transition, refreeze' (Weick \& Quinn, 1999, p372). Must overcome } \\
\text { inertia or resistance to change, resetting of structures and behaviors, establish } \\
\text { desired patterns of behavior. } \\
\text { Wide range of tools and techniques: Systems thinking, process engineering, work } \\
\text { flow design, SWOT analysis, team development etc. (Cummings \& Worley, } \\
\text { 2014). }\end{array}$ & $\begin{array}{l}\text { Objective is to make visible what is already underway, inducing self -organisation and } \\
\text { creating new models, to sense and engage with an emergent future (Scharmer, } \\
\text { 2009; Stacey, 2015, 2011). Reverse approach in which attempt is made to surface existing } \\
\text { mental models and tensions between them, to see resistance as a natural and productive } \\
\text { response to change (Weick and Quinn, 1999). } \\
\text { No set tools and techniques, approach based on participation and engagement with } \\
\text { diversity, a strong tolerance for living with complexity and paradox and an awareness of } \\
\text { power dynamics at play (Bushe \& Marshack, 2015) }\end{array}$ \\
\hline & $\begin{array}{l}\text { Leaders and other change agents play the role of prime mover following } \\
\text { prescribed steps of change implementation (Cameron \& Green, 2015). }\end{array}$ & $\begin{array}{l}\text { Role of leader is to deepen communication, to encourage fluidity in conversation, to act as } \\
\text { model of change, to embrace contradiction and paradox (Weick \& Quinn, 1999; Griffin \& } \\
\text { Stacey 2005). }\end{array}$ \\
\hline
\end{tabular}


It is informative to contrast how these alternative paradigms perceive organisations and organisational change and the consequent approach to strategy making and change leadership (Table 1), and how they might apply in higher education setting. Under the rational perspective a higher education institution is perceived as a distinctive entity, a purposive and adaptive actor with pre-set goals and with a visible structure designed to achieve these goals. This presumes a linear causality with structures and actions leading logically to expected outcomes. The perspective of change tends to be external and macro with HEIs viewed as a functioning system within a wider social environment or organisational field. Studies of change focus on how institutions respond to a wide range of environmental forces such as demographics, internationalisation, quality assurance, marketisation of research and learning programmes, or demand for new governance structures. This type of analysis in higher education is extensive ( see for example, Gornitzka, 1999; Huisman et al, 2016; Olsen, 2007). In the rational account of organisation, change within HEIs is depicted as a reorientation to better align the institution within the overall system of local and global issues. Change is initiated, usually from the top down, with a specified end state in mind. It is assumed that, by itself or in conjunction with others, the institution can construct such an envisioned end state, that it can identify and implement a set of actions to reach that goal and objectively monitor progress towards it (Kezar, 2013a). Analysis of such change and its management tends to focus on the transition process between start and optimal end state, on what sustains or impedes progress, on what should be happening. By contrast, the focus using the alternative paradigm is on what is actually happening in institutions (Mintzberg and Waters, 1989; Stacey, 2015). Under this emergent paradigm the analysis of change in higher education shifts to an internal, micro, perspective. Attention is directed to the daily work of the institution and the detail of how academics and others respond to the contextual demands placed on them resulting in outcomes that may sometimes lead to transformational change at institutional level. The study of micro- processes of change in higher education is much less extensive but see(Frølich et al., 2013; A. Kezar, 2013b; Nyhagen \& Baschung, 2013).

This alternative perspective and its emphasis on local context and interaction requires a very different approach to the formulation of institutional strategy and conceptualisation of change leadership to that contained in the dominant discourse. If one takes the overall purposive view, then institutional development can follow the standard process of committing to change, diagnosis of the current situation, planning and implementation of desired change and evaluation and institutionalization of change outcomes (Cummings \& Worley, 2015). This so-called diagnostic approach to strategic development and change is based on the assumption that objective data can be accessed to discover the current reality within the institution or institutional field and to benchmark it against some prescriptive model or future desired state (Bushe \& Marshak, 2009). There is an emphasis on seeking optimum solutions or strategies - an either/or decision-making process based on a dualist ontology that negates a both/and scenario. It is the rationale that underpins much institutional research and strategic planning in higher education focusing on the themes of core competencies, resource dependency and institutional positioning (Fumasoli \& Huisman, 2013; Hinton, 2012; Shattock, 2010).

A different mind-set is required when dealing with a scenario of continuous change; one that is cyclical, with constant ebb and flow of ideas, created by interaction and conversations between people for which there can be no predictable outcome and no end-state, and in which 
multiple solutions are often at play. In this case, the search is not for optimum solutions but for new possibilities. According to the alternative paradigm, surfacing and facing into the multiple and sometimes paradoxical forces that can exist in any change situation can be the source of new potentialities. The medium through which this is achieved is conversation; how people frame and talk about any situation, or what the dominant discourse is, plays a central role in how change comes about (Grant \& Marshak, 2011; Shaw, 2002). Therefore, instead of diagnosis followed by action planning, change leaders adopt a dialogic approach to strategic change and innovation (Gervase et al., 2015). Change strategy concentrates on expanding involvement in current discourses, encouraging the generative processes that lead to the construction of new institutional meanings or themes, disrupting existing mental models or patterns of thinking that allows for the emergence of new thoughts and action. Strategising is less about tools and techniques and more about active engagement by all change agents in organisational conversations, surfacing differences and patterns and encouraging experimentation with emergent ideas (Nevis et al, 2008; Olson \& Eoyang, 2001; Ray \& Gopplett, 2013; Scharmer, 2009; Weisbord \& Janoff, 2010).

The main case for embracing this emergent approach is that the complex and constantly evolving environment in which higher education operates requires a more complex conceptualisation of strategising for change (Askling \& Stensaker, 2002; Manning, 2013; Stewart et al, 2016). Within this complex environment, leaders must still attend to the processes that keep the institution functioning effectively. They must continuously analyse and be seen to respond to the evident needs of students, staff, and other stakeholders. The strategic management associated with the dominant paradigm, and normally deployed by positional leaders, i.e. the setting out of vision purpose and values, institutional planning, governance reform and targeted use of resources, recruitment and rewards, remains an essential part of the change process in HEIs (Kezar, 2013a). This rational approach works especially well when applying the logics of quality and the market to HEIs such as devising programmes or processes to meet the specific requirements of students or other stakeholders or adhering to prescribed accreditation standards. However, a broader strategic approach may be required by HEIs when refining their overall mission of responding to and influencing societal change or when encouraging innovation in its core work of teaching and research. In these instances, the kind of structural interventions described above may not apply as cause and effect but may only become apparent after the fact or may be indeterminate. Multiple or conflicting strategic demands may be at play, many of a local nature. The strategic challenge facing the institution is making sense of complex processes that are already under way, detecting and drawing attention to emergent change, and framing it in a way that can be absorbed into people's work (Weick \& Quinn, 1999). It requires a capacity to connect not just with existing themes but also to be able to sense emerging opportunities and engage in processes that are often open-ended and uncertain (Scharmer, 2009). In these situations, the emergent practices discussed in the alternative paradigm might better apply and policy and management focus need to shift to the local interactions that can bring forward new models or ways of thinking and on how individuals and groups experience or lead change.

Within the dominant, rational, paradigm, change agents or leaders within HEIs play the role of objective and detached observers whose job is to develop a vision and strategy for change and create the supporting systems infrastructure to effect such change. Their analyses and accounts of the institution and its interactions are based on abstractions of actual experience. 
These are intended to simplify, generalise or categorise forms and activities and to develop models, maps, or frameworks which can serve as useful aids in decision making (Stacey, 2011). The objective is to minimise confusion or ambiguity, to clarify goals or areas for improvement. This visionary and prescriptive model of leadership in higher education is most evident in national and international policy documents that call for the strengthening of leadership and management systems in higher education. The OECD, for example, talks of the need for senior institutional leaders to "provide the framework for linking individual academic work to institutional strategic goals...... by demonstrating the advantage of change, establishing a systematic forward-looking assessment of organisational direction, and defining the requirements and workloads needed to achieve the desired goals' (OECD, 2008 p. 238). Similar leadership strategies are echoed in many national and sectoral policy statements (Bleiklie \& Lange, 2010; Ekman et al, 2017; HEFCE, 2008; Trusso et al, 2007)

In the alternative, emergent, paradigm, the change leader is not just an observer or interpreter of events but is a committed participant immersed in whatever interactions are at play. The role of change leaders is extended beyond the application of trusted models and methods learned from past experience in effecting change to the engagement with others in making sense of a complex and uncertain present, collectively sensing what may emerge from this context and co-creating responses and actions deal with it (Bushe \& Marshak, 2016). Within a particular context and grouping, the role and status of the leader is also co-created and is based on the recognition of that person's capacity to guide this process. What is recognised is the capacity of that person to heighten awareness of what is already underway, the skill to surface resistance or underlying tensions around change, to articulate emergent themes arising from these tensions, a willingness to experiment with actions to put these ideas into effect and to live with the anxiety of the uncertain outcomes of such actions (Griffin \& Stacey, 2005). Leadership then is defined as the capacity of any system to sense and shape its future and a leader is any person or group that initiates change or innovation or is anyway engaged in shaping that future (Scharmer, 2009, p. 467). The concept of leadership is now firmly anchored to the processes of change that occur in all areas of the institution and is perceived as a process which is diffused or distributed throughout the institution rather than a quality possessed by an individual or something done by designated people.

In this way, the emergent, paradigm enhances our understanding of the position of those who see adoption of the rational model in HEIs as facilitation of managerialism and the steady erosion of shared governance (Deem \& Brehony, 2005; Franco-Santos et al., 2017;Rhoades, $\&$ Sporn, 2002) and adds insight and support to the responding case for a more distributed form of leadership in HEIs (Bolden et al, 2008; Jones \& Harvey, 2017; Kezar, 2008; Kezar $\&$ Lester, 2011). From this perspective, managerialism can be represented as an imbalance, an overreliance on one paradigm of organisation and organisational leadership. The call for more shared leadership is, in effect, a plea for a more balanced or inclusive perspective. Moreover, by giving a much deeper account of the nature of leadership the alternative paradigm helps to fill the 'discursive void' described by Ekman et al (2017, p.1) around what policy texts are referring to when they talk of the need for strong leadership to transform higher education. In the same way, it addresses the questions in the distributed leadership literature about what it is that is that is being distributed and concerns that the concept may constitute more rhetoric than reality (Bolden et al, 2009). The leadership as practice phenomena described in the emergent paradigm are very real and detail what is required if 
such leadership is to be effective or enabled in a higher education setting (Jones \& Harvey, 2017). This extends beyond the capacity of individuals to the dynamics that operate within and between institutional groups and to the culture of leadership within the entire institution. Real distributed leadership requires an acceptance of the emergent paradigm and the creation of a different narrative and mind-set around change strategy and leadership within the institution (Bushe \& Marshak, 2016).

Table 2 Rethinking strategy and change leadership in higher education using an emergent perspective of change

\begin{tabular}{|c|c|c|}
\hline $\begin{array}{c}\text { Institutional } \\
\text { Activity }\end{array}$ & Planned Perspective & Emergent Perspective \\
\hline Strategising & $\begin{array}{l}\text { Alignment with environment. } \\
\text { Seeking legitimacy } \\
\text { Focus on institutional research and } \\
\text { planning for the future, on best use } \\
\text { of existing knowledge and } \\
\text { competences. } \\
\text { Strategy as intent, construction of } \\
\text { clear corporate goals, creation of } \\
\text { positive image and reputation. }\end{array}$ & $\begin{array}{l}\text { Connection with emerging trends. } \\
\text { Search for distinctiveness. } \\
\text { Focus on present work of } \\
\text { institution, on exploration and } \\
\text { experimentation. } \\
\text { Strategy as practice, attending to } \\
\text { the interactions that enable or } \\
\text { constrain change; evolution of } \\
\text { individual and collective identity. }\end{array}$ \\
\hline $\begin{array}{c}\text { Change } \\
\text { Leadership }\end{array}$ & $\begin{array}{l}\text { Designated strong leaders that can } \\
\text { envision and deliver strategic goals. } \\
\text { Focus on leader characteristics and } \\
\text { behaviour. } \\
\text { Deliberate development of leaders } \\
\text { to create a competent management } \\
\text { cohort. }\end{array}$ & $\begin{array}{l}\text { Diffuse or distributed leadership } \\
\text { that co-creates change. } \\
\text { Focus on a leadership process } \\
\text { linked with change. } \\
\text { Continuous development of } \\
\text { leadership capacity across the } \\
\text { institution. }\end{array}$ \\
\hline
\end{tabular}

\section{Including the Emergent Paradigm in the Organisation of Higher Education}

This leads us to the question of what organisational configurations could evolve in HEIs to accommodate the emergent paradigm and the associated reframing of core institutional activities of strategising and leading change (Table 2). To what extent are these alternative paradigms being currently accommodated within HEIs? How can HEIs maintain legitimacy with key stakeholders and funders by being seen to align with societal needs and adopting governance forms that are transparent and accountable while at the same time tapping into the latent sources of change and innovation that exist within the institution, but that cannot always be planned or accounted for? 
A study of the literature on how the rational model is being adopted in higher education suggests that an interaction between the alternative paradigms may already be in play and that, as in any contest of ideas, the outcome is unpredictable given the emergent nature of the process. The empirical evidence supports the notion of some form of hybridization of organisational form taking place in higher education. A prime example is a team study of the adoption of the complete organisational form - autonomous, rational, hierarchical - in 26 European universities across eight European states which showed individual institutions display these characteristics in varying degrees (Bleikli et al, 2017; Seeber et al., 2015). Moreover, it found that the process of adoption of these dimensions would seem to be a complex one which cannot be reduced to an either/or dichotomy nor can institutional responses be described on some spectrum of adoption or resistance. Instead, it appears that professional academic practices are not being replaced by managerial ones but are blended in some way and that managerial and collegial models of decision making may not always be at odds. Much of the real strategic decision making takes place outside the rational planning model (Frølich et al, 2017). Other national and institutional studies point in the same direction. Blaschke et al's (2014) case study of the reorganization of a German HEI showed that rather than 'managerialism' replacing 'collegialism' organizational change unfolded in oscillating sequences or patterns of communication at a micro level between various institutional entities rather than some linear top down process. The findings furthermore showed much of these communications were peripheral to the core activities of research and teaching which remained largely autonomous, despite increasing managerial regulation. A review of national change patterns in Germany and Norway showed 'no indication of a one-way street towards a brave new world of corporate enterprise organisations in higher education' (Bleiklie \& Lange, 2010 p. 189). The change emphasis in Germany seemed to focus on structural competition within the sectors with some hybrid form of governance emerging at institutional level between the new managerial and the former Humboldtian model. In Norway, as in Sweden (Eckman et al, 2017), the reform focussed on the installation of institutional leadership at departmental level and a reconfiguration of relations with state funding bodies. A study of the interaction between academic and administrative functions in an Austrian technical university showed a hybridisation of institutional forms and activities based on competing professional academic and corporate administrative logics (Preymann et al, 2016). De Boer et al's (2007) study of organisational transformation in Dutch universities has shown that while there is a visible trend towards the adoption of the rational organisational model it has occurred alongside more traditional patterns of organising from which it could be argued 'a new archetype of organization is emerging' (p. 43). As a final example, a transatlantic comparison by Ramirez and Christensen (2013) of the recent history of organisational development in the University of Oslo and Stanford University indicated that while both more explicitly function as organisational actors they do so in ways that reflect their very different historical roots.

These and other studies imply that while there is a common thread of adoption of the rational model, the way it is enacted is context specific, iterative, and emerges from local competing ideas of organising, all of which suggest that the kind of dynamics described in the emergent paradigm of organisational change may be at play. If that is the case, such local interaction and diversity are likely to encourage diverse and unique outcomes, with each institution devising its own strategic processes and forms of governance and leadership in a way that cannot be predetermined or imposed. However, an important aspect of the emergent 
paradigm of change is that while the outcome of such change processes may not always be predictable, they are not simply random or merely fortuitous. Outcomes arise from the quality of the interaction taking place and, critically, on its ability to bring underlying tensions to light. In turn, this depends on the diversity of those involved in such interactions, the clarity and authenticity of exchanges between people, an acknowledgement of the power configurations that confer or limit choice and the institutional values and norms that shape the choices that are being made (Stacey, 2011); not quite the random garbage can model of university decision making as depicted by Cohen, March and Olsen (1972). It follows that greater policy and research attention needs to be directed towards the workings of those processes of change and the actors involved in them if the potential negative outcomes of stifling local leadership and innovation are to be avoided (Bolden et al., 2008; Deem \& Brehony, 2005; Franco-Santos et al., 2017) and the more positive outcomes of professional growth, enhancement of local leadership, and innovative organisational outcomes are to happen (Clark, 2004; Kezar \& Lester, 2011; O’Meara, 2008). If policymakers and leaders in HEIs cannot choose the future organisational configuration of HEIs they can play a creative and influential role in how it unfolds. In practical terms, this involves a shift in mind-set about the nature and function of strategic management and leadership in higher education, one that derives from a broader conceptualisation of the university as an organisational actor.

The current stance on strategising in higher education tends to focus on goal setting and identity construction. Strategising is largely influenced by a desire to achieve legitimacy, and thereby access to resources, by being seen to respond to environmental demands while maintaining the institutional specificity of a third level institution (Frølich et al., 2013; Fumasoli \& Huisman, 2013; Krucken et al 2006). Using the emergent paradigm, a different and more nuanced account of the institution and how it relates to its environment emerges. The focus of attention shifts from a deterministic adaptation to environmental pressure to the interactive role played by all kinds of organisational actors in continuously shaping the institutional environment. Change is perceived less as a conformance or reaction to specific environmental forces and more a sensing of the emergence of new themes arising from tensions between opposing ideas or interplay between various strategic intents. The emergent paradigm is one that embraces ambivalence and paradox and encourages institutions and people working in them to live with or leverage those opposing tensions rather than attempting to resolve them, to accentuate the positive significance of each polarity and modulate the negative or to reframe them in innovative ways (Stacey, 2011; Johnson, 2014). The isomorphic tendency towards legitimacy is tempered with the desire of people to assert their individual and collective identity and for institutions to achieve distinctiveness within this environment (Zhao et al 2017).

To realise this, the policy and research focus shifts from strategic content or outcomes to strategy as process; something that is being continuously carried out within institutions and the field of higher education. Policy makers and researchers need to pay more attention to the interactions that occur at field and institutional level and the type of interventions needed to ensure that more innovative outcomes result from such activity, and to how people experience change. This emphasis on the process of strategising suggests a research agenda that is closer to that outlined in the strategy as practice literature on how organizational and institutional practices and politics enable and constrain local strategic action, on the strategy work that takes place, and the role of the various actors involved (Frølich et al., 2013, 2017; Jarzabkowski et al, 2007; Vaara \& Whittington, 2012). 
This inevitably leads to a rethinking on the role of local leadership in initiating and enacting institutional change. Current policy stances tend towards a visionary and directive form of leadership that deploys strategic planning and monitoring to steer higher education in a particular direction. Such policies are prescriptive on the inputs and resources needed and the expected outcomes - better managed and socially engaged HEIs - but say little about the actual leadership practices that can bring about these outcomes. However, more recent studies on leaders and their role in bringing about change do focus on practice, on the dynamics of change and the role of individuals and groups in effecting change (Bolden et al., 2012; Hempsall, 2014; Jones \& Harvey, 2017; Kezar \& Lester, 2011). They draw attention to the discursive mechanisms of change, to the dynamics of power that influence those mechanisms and to the role that change plays in the construction and iteration of people's values and identities. These are themes that are common to descriptions of leadership contained within the alternative, emergent, paradigm (Bushe \& Marshak, 2016; Crevani et al 2010; Griffin \& Stacey, 2005). Using the paradigm and studies as a lens, a different framework for policy and research on leadership emerges. It involves a shift in attention away from the role and characteristics of individual leaders towards the process of leadership and its link with change. From this perspective, leadership development expands from the enhancement of competences in individuals occupying formal leadership roles to the development of leadership capacity across the institution. Unbundling the factors affecting change outcomes outlined in this literature leads us to define three levels of investigation and development that can enhance that capacity:

- The factors that strengthen of the ability of individual academic or other leaders to deal with uncertainty and paradox, to develop a level of self-awareness and motivation that allows them to retain and develop their own identity while engaging actively with others (e.g. Bushe, 2010; Parks, 2005)

- The enablers and constraints on groups to build trust, hold space for resistance or contradictory positions, let go of previous mental models and form a collective approach to experimenting with new ones. Central to building such trust is the recognition of the power configurations, and associated sense of inclusion and exclusion, that can emerge within and between institutional functions. Also of interest are the interaction of values within groups that affect ethical decision making (Griffin \& Stacey, 2005; Hardy et al., 2005; Thomas \& Hardy, 2011)

- The organisational structures and supports that are needed to underpin this type of open and value-based conversation, providing a 'safe container' for experimentation and resolution of conflicting ideas. For example, research along the lines of that of O'Reilly \& Tushman (2008) on how particular structures can augment the creative output of innovation processes could be extended to a higher education setting.

In general, the focus of research shifts from analysis of actions and outcomes to an exploration of individual experience of change processes so as to determine how these interrelated factors affect change (Stacey \& Griffin, 2005). Policy makers and institutional managers apply more resources to the development of leadership capacity in house, with a focus on relationship building between people at institutional and sectoral level. Moreover, thinking of leadership as diffuse places an onus on individuals and groups to reflect on and attend to their own development. Academic autonomy already implies responsibility for 
professional development and that can be extended to include personal growth and the capacity to lead (O'Meara et al).

\section{Conclusion}

Deploying the polar descriptions of organisation and organisational change described above helps bring differences in approach to strategy making and change leadership in higher education into sharper focus. This paper suggests a more pluralist approach whereby HEIs adopt an emergent model of organisation in conjunction with the dominant rational paradigm. Tempering the dominant model with the emergent paradigm means directing attention to the core work of the institution and on how it brings about institutional change resulting in a much more nuanced perception of strategy management and leadership and a different institutional logic. It results in concentration on distinctiveness and diversity over conformance, focussing equally on the nature of interactions that allow learning and innovation to happen as on planned outcomes. While there are indications that such a tempering or hybridisation of paradigms may already be happening within higher education, there is a need for a more coherent theoretical framework in which to study and direct that process. The managerial and scholarly challenge is to devise configurations at system and institutional level in which both organisational paradigms can fruitfully coexist.

In effect, this could involve a partial reversal or deinstitutionalisation of the type of governance structures, mental models and values that have influenced higher education strategy and leadership in recent decades. This will require a significant reorientation of existing administrative arrangements and a rethinking of the role of academia in organisational development, which may take time and considerable effort. However, we believe that the process will be driven by a number of factors. Firstly, there is the continuing functional and political pressure on higher education to be more agile and responsive to rapidly changing social needs which the alternative paradigm suggested in this paper would seem to better facilitate. Secondly, the findings of transnational studies on adoption of the complete organisational model is beginning to stimulate deeper discussion on the organisational forms best suited to higher education in its varying contexts. Thirdly, we believe that growing doubts over the effectiveness or appropriateness of some of the tools of rational management most notably strategic planning and quality rankings may lead to a questioning of the logic that informs the use of such methods. Lastly, as the world of business begins to move towards this more holistic form of organisational thinking we believe that HEIs may follow suit.

The first steps then are to build on these trends, to create the conditions in which more agile and distributed leadership can prosper, to expand research into the micro processes that foster creativity and distinctiveness, to develop alternative approaches to strategic direction and institutional assessment, and to expose institutions to a wider array of organisational theories and practice. In this scenario, the focus of debate shifts from the abstract and global aim of turning the university into an organisation towards the more local and immediate task of enabling one's organisation become the university it wants to be. 


\section{References}

Askling, B., \& Stensaker, B. (2002). Academic leadership: Prescriptions, practices and paradoxes. Tertiary Education and Management, 8(2), 113-125. https://doi.org/10.1080/13583883.2002.9967073

Bastedo, M. N. (2012). The Organization of Higher Education: Managing Colleges for a New Era. JHU Press.

Blaschke, S., Frost, J., \& Hattke, F. (2014). Towards a micro foundation of leadership, governance, and management in universities. Higher Education, 68(5), 711-732. https://doi.org/10.1007/s10734-014-9740-2

Bleiklie, I., Enders, J., \& Lepori, B. (2017). Managing Universities: Policy and Organizational Change from a Western European Comparative Perspective. Springer.

Bleiklie, I., \& Lange, S. (2010). Competition and leadership as drivers in German and Norwegian university reforms. Higher Education Policy, 23(2), 173-193.

Bolden, R., Gosling, J., Anne O ' Brien, Peters, K., Ryan, M., Haslam, A., ... Winklemann, K. (2012). Academic Leadership: Changing conceptions, identities and experiences in UK higher education (p. ). Leadership Foundation for Higher Education. https://doi.org/10.13140/2.1.1957.6009

Bolden, R., Petrov, G., \& Gosling, J. (2008). Tensions in Higher Education Leadership: Towards a Multi-Level Model of Leadership Practice. Higher Education Quarterly, 62(4), 358-376. https://doi.org/10.1111/j.1468-2273.2008.00398.x

Bolden, R., Petrov, G., \& Gosling, J. (2009). Distributed Leadership in Higher Education: Rhetoric and Reality. Educational Management Administration \& Leadership, 37(2), 257-277. https://doi.org/10.1177/1741143208100301

Bolman, L. G., \& Gallos, J. V. (2011). Reframing academic leadership (1st ed). San Francisco, CA: Jossey-Bass.

Brunsson, N., \& Sahlin-Andersson, K. (2000). Constructing organizations: The example of public sector reform. Organization Studies, 21(4), 721-746.

Bushe, G. R., \& Marshak, R. J. (2009). Revisioning Organization Development: Diagnostic and Dialogic Premises and Patterns of Practice. The Journal of Applied Behavioral Science, 45(3), 348-368. https://doi.org/10.1177/0021886309335070

Bushe, G. R., \& Marshak, R. J. (2016). The Dialogic Mindset: Leading Emergent Change in a Complex World - ProQuest. Organization Development Journal, 34(1), 37-65.

Bushe, Gervase R. (2010). Clear Leadership: Sustaining Real Collaboration and Partnership at Work (Revised Edition edition). Boston: Nicholas Brealey.

Bushe, Gervase R., \& Marshak, R. J. (Eds.). (2015). Dialogic organization development: the theory and practice of transformational change (First Edition). Oakland: BerrettKoehler Publishers, a BK Business book.

Clark, B. R. (2004). Delineating the Character of the Entrepreneurial University. Higher Education Policy, 17(4), 355-370. https://doi.org/10.1057/palgrave.hep.8300062

Cohen, M., March, J., \& Olsen, J. (1972). A Garbage Can Model of Organizational

Choice. Administrative Science Quarterly, 17(1), 1-25. doi:10.2307/2392088

Crevani, L., Lindgren, M., \& Packendorff, J. (2010). Leadership, not leaders: On the study of leadership as practices and interactions. Scandinavian Journal of Management, 26(1), 77-86. https://doi.org/10.1016/j.scaman.2009.12.003 
Cummings, T. G., \& Worley, C. G. (2015). Organization development \& change (10e [edition]). Stamford, CT: Cengage Learning.

De Boer, H. F., Enders, J., \& Leisyte, L. (2007). PUBLIC SECTOR REFORM IN DUTCH HIGHER EDUCATION: THE ORGANIZATIONAL TRANSFORMATION OF THE UNIVERSITY. Public Administration, 85(1), 27-46. https://doi.org/10.1111/j.1467-9299.2007.00632.x

Deem R., \& Brehony, K. J. (2005). Management as ideology: the case of 'new managerialism' in higher education. Oxford Review of Education, 31(2), 217-235. https://doi.org/10.1080/03054980500117827

Ekman, M., Lindgren, M., \& Packendorff, J. (2017a). Universities need leadership, academics need management: discursive tensions and voids in the deregulation of Swedish higher education legislation. Higher Education, 1-23. https://doi.org/10.1007/s10734-017-0140-2

Ekman, M., Lindgren, M., \& Packendorff, J. (2017b). Universities need leadership, academics need management: discursive tensions and voids in the deregulation of Swedish higher education legislation. Higher Education. https://doi.org/10.1007/s10734-017-0140-2

Enders, J., de Boer, H., \& Weyer, E. (2013). Regulatory autonomy and performance: the reform of higher education re-visited. Higher Education, 65(1), 5-23. https://doi.org/10.1007/s10734-012-9578-4

Franco-Santos, M., Nalick, M., Rivera-Torres, P., \& Gomez-Mejia, L. (2017). Governance and Well-being in Academia: Negative Consequences of Applying an Agency Theory Logic in Higher Education: Governance and Well-being in Academia. British Journal of Management, 28(4), 711-730. https://doi.org/10.1111/1467-8551.12249

Frølich, N., Huisman, J., Slipersæter, S., Stensaker, B., \& Bótas, P. C. P. (2013). A reinterpretation of institutional transformations in European higher education: strategising pluralistic organisations in multiplex environments. Higher Education, 65(1), 79-93. https://doi.org/10.1007/s10734-012-9582-8

Frølich, N., Stensaker, B., \& Huisman, J. (2017). Understanding Strategy Practices in Universities. In Managing Universities (pp. 167-188). Palgrave Macmillan, Cham. https://doi.org/10.1007/978-3-319-53865-5_7

Fumasoli, T., \& Huisman, J. (2013). Strategic Agency and System Diversity: Conceptualizing Institutional Positioning in Higher Education. Minerva, 51(2), 155 169. https://doi.org/10.1007/s11024-013-9225-y

Gornitzka, Å. (1999). Governmental policies and organisational change in higher education. Higher Education, 38(1), 5-31. https://doi.org/10.1023/A:1003703214848

Grant, D., \& Marshak, R. J. (2011). Toward a Discourse-Centered Understanding of Organizational Change. The Journal of Applied Behavioral Science, 47(2), 204-235. https://doi.org/10.1177/0021886310397612

Griffin, D., \& Stacey, R. D. (2005). Complexity and the Experience of Leading Organizations. Taylor \& Francis.

Hardy Cynthia, Lawrence Thomas, \& Grant David. (2005). Discourse and Collaboration: The Role of Conversations and Collective Identity. Academy of Management Journal, $30(1), 58-77$.

HEFCE. (2008a). HEFCE strategic plan 2006-11. Retrieved January 6, 2018, from http://www.hefce.ac.uk/data/year/2008/HEFCE,strategic,plan,2006-11,/

Hempsall, K. (2014). Developing leadership in higher education: perspectives from the USA, the UK and Australia. Journal of Higher Education Policy and Management, 36(4), 383-394. https://doi.org/10.1080/1360080X.2014.916468 
Hinton, K. E. (2012). A practical guide to strategic planning in higher education. Retrieved from http://public.eblib.com/choice/publicfullrecord.aspx? $\mathrm{p}=3544821$

Huisman, J., Boer, H. de, Dill, D. D., \& Souto-Otero, M. (2016). The Palgrave International Handbook of Higher Education Policy and Governance. Springer.

Jarzabkowski, P., Balogun, J., \& Seidl, D. (2007). Strategizing: The challenges of a practice perspective. Human Relations, 60(1), 5-27. https://doi.org/10.1177/0018726707075703

Johnson, B. (2014). Reflections: A Perspective on Paradox and Its Application to Modern Management. The Journal of Applied Behavioral Science, 50(2), 206-212. https://doi.org/10.1177/0021886314524909

Jones, S., \& Harvey, M. (2017). A distributed leadership change process model for higher education. Journal of Higher Education Policy and Management, 39(2), 126-139. https://doi.org/10.1080/1360080X.2017.1276661

Kezar, A. (2013a). How Colleges Change: Understanding, Leading, and Enacting Change. Routledge.

Kezar, A. (2013b). Understanding sensemaking/sensegiving in transformational change processes from the bottom up. Higher Education, 65(6), 761-780. https://doi.org/10.1007/s10734-012-9575-7

Kezar, A. J. (Ed.). (2008). Rethinking leadership in a complex, multicultural, and global environment: new concepts and models for higher education (1st ed). Sterling, Va: Stylus Pub.

Kezar, A. J., Carducci, R., \& Contreras-McGavin, M. (2006). Rethinking th. ASHE Higher Education Report, 31(6), 1-218. https://doi.org/10.1002/aehe.3106

Kezar, A. J., \& Lester, J. (2011). Enhancing campus capacity for leadership: an examination of grassroots leaders in higher education. Stanford, California: Stanford University Press.

Krucken, G., Castor, C., Kosmutzky, A., \& Torka, M. (Eds.). (2006). Towards a Multiversity?: Universities between Global Trends and National Traditions. Bielefeld; Piscataway, NJ: Transcript Verlag.

Krücken, G., \& Meier, F. (2006). Turning the university into an organizational actor. Globalization and Organization: World Society and Organizational Change, 241257.

Manning, K. (2013). Organizational theory in higher education. New York, NY: Routledge.

Marginson, S. (2006). Putting "Public" Back into the Public University. Thesis Eleven, 84(1), 44-59. https://doi.org/10.1177/0725513606060519

Meyer, J. W. (2010). World Society, Institutional Theories, and the Actor. Annual Review of Sociology, 36(1), 1-20. https://doi.org/10.1146/annurev.soc.012809.102506

Mintzberg H., Waters J.A. (1989) Of Strategies, Deliberate and Emergent. In: Asch D.,

Bowman C. (eds) Readings in Strategic Management. Palgrave, London

Molesworth, M., Scullion, R., \& Nixon, E. (2010). The Marketisation of Higher Education. Routledge.

Musselin, C. (2006). Are Universities Specific Organisations? In Krucken, G, Kosmutzky, A, \& Torka, M (Eds.), Towards a Multiversity? Universities between Global Trends and National Traditions. Biefeld.

Nevis Edwin, Melnick, Joseph, \& Nevis, Sonia. (2008). Organizational Change through Powerful Micro-Level Interventions The Cape Cod Model. OD PRACTITIONER, 40(3). 
Nyhagen, G. M., \& Baschung, L. (2013). New organisational structures and the transformation of academic work. Higher Education, 66(4), 409-423. https://doi.org/10.1007/s10734-013-9612-1

OECD. (2008). Tertiary Education for the Knowledge Society: VOLUME 1 : Special features: Governance, Funding, Quality - VOLUME 2: Special features: Equity, Innovation, Labour Market, Internationalisation - OECD. Retrieved April 11, 2017, from http://www.oecd.org/education/skills-beyondschool/tertiaryeducationfortheknowledgesocietyvolume1 specialfeaturesgovernancefu ndingqualityvolume2specialfeaturesequityinnovationlabourmarketinternationalisation.htm

Olsen, J. P. (2007). The Institutional Dynamics of the European University. In University Dynamics and European Integration (pp. 25-54). Springer, Dordrecht. https://doi.org/10.1007/978-1-4020-5971-1_2

Olson, E. E., \& Eoyang, G. H. (2001). Facilitating organization change: lessons from complexity science. San Francisco, Calif: Jossey-Bass/Pfeiffer.

O’Meara, K., Terosky, A. L., \& Neumann, A. (2008). Faculty careers and work lives: a professional growth perspective. John Wiley \& Sons.

O'Reilly, C. A., \& Tushman, M. L. (2008). Ambidexterity as a dynamic capability: Resolving the innovator's dilemma. Research in Organizational Behavior, 28, 185206. https://doi.org/10.1016/j.riob.2008.06.002

Parks, S. D. (2005). Leadership Can Be Taught: A Bold Approach for a Complex World. Harvard Business Review Press.

Preymann, S., Sterrer, S., Ehrenstorfer, B., Gaisch, M., \& Aichinger, R. (2016). Harmonising the Interface Between Academic and Administrative Mind-Sets. In Global Challenges, National Initiatives, and Institutional Responses (pp. 237-236). SensePublishers, Rotterdam. https://doi.org/10.1007/978-94-6300-675-0_12

Ramirez, F. O. (2012). The world society perspective: concepts, assumptions, and strategies. Comparative Education, 48(4), 423-439. https://doi.org/10.1080/03050068.2012.693374

Ramirez, F. O., \& Christensen, T. (2013). The formalization of the university: Rules, roots, and routes. Higher Education, 65(6), 695-708.

Ray, K, \& Gopplett, J. (2013). From Special to Ordinary Dialogic OD in Day-to-Day Complexity. OD PRACTITIONER, 45(1), 42-46.

Rhoades, G, \& Sporn, B. (2002). New models of management adn shifing costs of production: Europe and the United States. Tertiary Education and Management 8: 3 28, 2002., 8, 3-28.

Scharmer, C. O. (2009a). Theory U: Leading from the Future as It Emerges (1 edition). San Francisco, Calif.; London: Berrett-Koehler Publishers.

Scott, W. (2015). Organizatonal theory and higher education. Journal of Orgnanization Theory in Education, 1(1). Retrieved from www.organizationaltheoryineducation.com.

Scott, W. R., \& Davis, G. F. (2007). Organizations and organizing: rational, natural, and open systems perspectives (1. ed). Upper Saddle River, NJ: Pearson Prentice Hall.

Seeber, M., Lepori, B., Montauti, M., Enders, J., de Boer, H., Weyer, E., ... Reale, E. (2015). European Universities as Complete Organizations? Understanding Identity, Hierarchy and Rationality in Public Organizations. Public Management Review, 17(10), 14441474. https://doi.org/10.1080/14719037.2014.943268

Shattock, M. (2010). Managing Successful Universities. McGraw-Hill Education (UK).

Shaw, P. (2002). Changing conversations in organizations: a complexity approach to change. London; New York: Routledge. 
Stacey, R. (2015). Understanding organizations as complex responsive processes of relating. Dialogic Organization Development. The Theory and Practice of Transformational Change.

Stacey, R. D. (2011). Strategic management and organisational dynamics: the challenge of complexity to ways of thinking about organisations (6th ed). Harlow, England ;New York: Financial Times Prentice Hall.

Stacey, R. D., \& Griffin, D. (2005). A Complexity Perspective on Researching Organizations: Taking Experience Seriously. Taylor \& Francis.

Stacey, R. D., Griffin, D., \& Shaw, P. (2000). Complexity and management: fad or radical challenge to systems thinking? London; New York: Routledge.

Stacey, R. D., \& Mowles, C. (2016). Strategic management and organisational dynamics: the challenge of complexity to ways of thinking about organisations (Seventh edition). Harlow, England: Pearson Education.

Stewart, B., Khare, A., \& Schatz, R. (2016). Volatility, Uncertainty, Complexity and Ambiguity in Higher Education. In O. Mack, A. Khare, A. Krämer, \& T. Burgartz (Eds.), Managing in a VUCA World (pp. 241-250). Springer International Publishing. https://doi.org/10.1007/978-3-319-16889-0_16

Thomas, R., \& Hardy, C. (2011). Reframing resistance to organizational change. Scandinavian Journal of Management, 27(3), 322-331. https://doi.org/10.1016/j.scaman.2011.05.004

Trusso, A., European University Association, \& Conraths, B. (2007). Managing the university community: exploring good practice. Brussels: European University Association.

Tsoukas, H, \& Chia, R. (2002). On Organizational Becoming - Rethinking Organizational Change. Organization Science, 13(5), 567-582.

Vaara, E., \& Whittington, R. (2012). Strategy-as-Practice: Taking Social Practices Seriously. The Academy of Management Annals, 6(1), 285.

Van de Ven, A. H., \& Poole, M. S. (2005). Alternative approaches for studying organizational change. Organization Studies, 26(9), 1377-1404.

Van de Ven, A. H., Poole, M. S., \& others. (1995). Explaining development and change in organizations. Academy of Management Review, 20(3), 510-540.

Weick, K. E., \& Quinn, and R. E. (1999). Organizational Change and Development. Annual Review of Psychology, 50(1), 361-386. https://doi.org/10.1146/annurev.psych.50.1.361

Weick, K, \& Quinn, R. E ,. (1999). Organizational Change and Development. Annu. Rev. Psychol., 50, 361-386.

Weisbord, M., \& Janoff, S. (2010). Future Search: Getting the Whole System in the Room for Vision, Commitment, and Action. Berrett-Koehler Publishers.

Whitley, R. (2008). Construction universities as strategic actors: Limitations and variations (Working Paper No. 557). Manchester Business School working paper. Retrieved from https://www.econstor.eu/handle/10419/50654

Zhao, E. Y., Fisher, G., Lounsbury, M., \& Miller, D. (2017). Optimal distinctiveness: Broadening the interface between institutional theory and strategic management. Strategic Management Journal, 38(1), 93-113. https://doi.org/10.1002/smj.2589 